BMC

Plant Biology

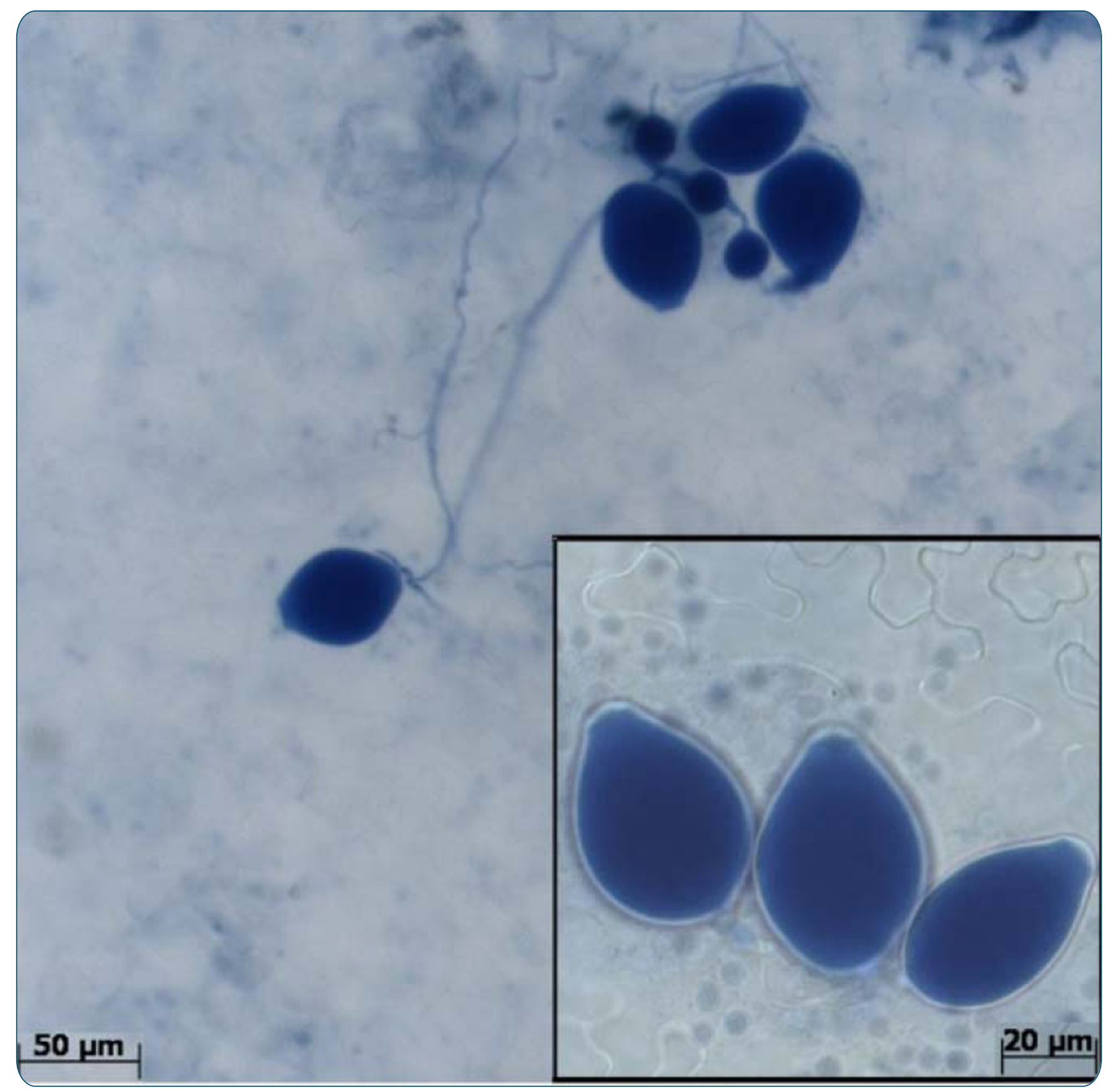

Arabidopsis nonhost resistance gene PSS1 confers immunity against an oomycete and a fungal pathogen but not a bacterial pathogen that cause diseases in soybean

Sumit et al. 


\title{
Arabidopsis nonhost resistance gene PSS1 confers immunity against an oomycete and a fungal pathogen but not a bacterial pathogen that cause diseases in soybean
}

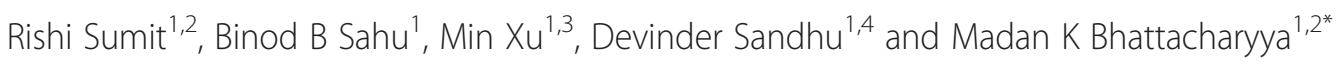

\begin{abstract}
Background: Nonhost resistance (NHR) provides immunity to all members of a plant species against all isolates of a microorganism that is pathogenic to other plant species. Three Arabidopsis thaliana PEN (penetration deficient) genes, PEN1, 2 and 3 have been shown to provide NHR against the barley pathogen Blumeria graminis f. sp. hordei at the prehaustorial level. Arabidopsis pen1-1 mutant lacking the PEN1 gene is penetrated by the hemibiotrophic oomycete pathogen Phytophthora sojae, the causal organism of the root and stem rot disease in soybean. We investigated if there is any novel nonhost resistance mechanism in Arabidopsis against the soybean pathogen, P. sojae.
\end{abstract}

Results: The P. sojae susceptible (pss) 1 mutant was identified by screening a mutant population created in the Arabidopsis pen 1-1 mutant that lacks penetration resistance against the non adapted barley biotrophic fungal pathogen, Blumeria graminis f. sp. hordei. Segregation data suggested that PEN1 is not epistatic to PSS1. Responses of pss 1 and pen1-1 to P. sojae invasion were distinct and suggest that PSS1 may act at both pre- and post-haustorial levels, while PEN1 acts at the pre-haustorial level against this soybean pathogen. Therefore, PSS1 encodes a new form of nonhost resistance. The pss1 mutant is also infected by the necrotrophic fungal pathogen, Fusarium virguliforme, which causes sudden death syndrome in soybean. Thus, a common NHR mechanism is operative in Arabidopsis against both hemibiotrophic oomycetes and necrotrophic fungal pathogens that are pathogenic to soybean. However, PSS1 does not play any role in immunity against the bacterial pathogen, Pseudomonas syringae pv. glycinea, that causes bacterial blight in soybean. We mapped PSS1 to a region very close to the southern telomere of chromosome 3 that carries no known disease resistance genes.

Conclusions: The study revealed that Arabidopsis PSS1 is a novel nonhost resistance gene that confers a new form of nonhost resistance against both a hemibiotrophic oomycete pathogen, P. sojae and a necrotrophic fungal pathogen, F. virguliforme that cause diseases in soybean. However, this gene does not play any role in the immunity of Arabidopsis to the bacterial pathogen, P. syringae pv. glycinea, which causes bacterial blight in soybean. Identification and further characterization of the PSS1 gene would provide further insights into a new form of nonhost resistance in Arabidopsis, which could be utilized in improving resistance of soybean to two serious pathogens.

Keywords: Phytophthora sojae susceptible (pss1), Sequence-based polymorphic (SBP) marker, Fusarium virguliforme, Phytophthora sojae, Pseudomonas syringae pv. glycinea

\footnotetext{
* Correspondence: mbhattac@iastate.edu

'Department of Agronomy, lowa State University, Ames, IA 50011, USA

${ }^{2}$ Molecular Cellular and Developmental Biology Interdepartmental Graduate program, lowa State University, Ames, IA 50011, USA

Full list of author information is available at the end of the article
} 


\section{Background}

Plants are exposed to an innumerable number of pathogenic organisms on a daily basis. However, because of immunity mechanisms only a few pathogens can infect and cause diseases in a particular crop species. One of the less understood immunity mechanisms is nonhost resistance (NHR), exhibited by all members of a plant species against non adapted pathogens [1,2]. The main NHR mechanisms were thought to be 1) incompatibility of non adapted pathogen with the physiology of nonhost plants and 2) inability of non adapted pathogens to overcome the plant defenses [3]. The first gene known to confer Arabidopsis NHR against a non adapted bacterial pathogen, Pseudomonas syringae pv. phaseolicola, is NONHOST1 (NHO1) which encodes a glycerol kinase $[4,5]$. NHO1 has also been shown to play an important role in the expression of gene-specific resistance against a bacterial pathogen [4].

NHR acts in two layers against the biotrophic fungal pathogens [6,7]. The first layer of NHR suppresses the invasion by non adapted pathogens at the pre-haustorial level. Three NHR genes, PEN1, PEN2 and PEN3, required for penetration resistance of Arabidopsis against the non adapted barley biotrophic fungal pathogen, Blumeria graminis f. sp. hordei have been isolated [6-8]. These genes act at the prehaustorial stage of the pathogen invasion [9]. PEN1 encodes a soluble N-ethylmalemide sensitive attached receptor (SNARE) protein, which is involved in vesicle fusion and exocytosis of toxic compounds to the pathogen infection sites [8]. PEN2 encodes a glycosyl hydrolase, which has been localized to the peroxisomes [6]. PEN3 encodes an ATPbinding cassette $(\mathrm{ABC})$ protein of the plasma membrane [7]. Cytological studies have demonstrated that PEN2 and PEN3 work together to generate and transport toxic chemicals into the infection sites [10]. The first layer of NHR prevents the biotrophic fungal pathogens from penetration and development of feeding structures, haustoria. Fungal pathogens that overcome the first layer of NHR encounter a post-haustorial defense mechanism. Some of the genes involved in the second layer of NHR in Arabidopsis are EDS1, PAD4 and SAG101 that are involved in plant defenses [6]. Downstream antagonistic defense pathways regulated by salicylic acid (SA) and the jasmonic acid (JA) are activated upon infection with biotrophic and necrotrophic pathogens, respectively [11]. SA and JA pathways are shown to be involved in the expression of nonhost resistance against the cowpea rust, Uromyces vignae, in Arabidopsis [12]. Similarly, studies of mutants lacking PEN1, 2, and 3 established that SA and JA pathways are also involved in the expression of nonhost resistance in Arabidopsis against the soybean pathogen Phakopsora pachyrhizi that causes the Asian soybean rust [13].
Recognition of pathogen associated molecular patterns (PAMPs) of non adapted pathogens by PAMP recognition receptors (PRRs) triggers the PAMP-triggered immunity (PTI) in nonhost species [14]. Recent studies have shown that PTI plays a major role in NHR [15]. Both chemical and physical barriers induced by PTI restrict non-adapted pathogens from invading nonhost species. Physical barriers include callose deposition at the infection sites and preformed barriers such as waxy coating on leaves. Chemical barriers include deposition of various reactive oxygen species (ROS) such as hydrogen peroxide and phenolic compounds at the infection site $[16,17]$.

The plant responses to pathogenic invasions can be classified into two broad groups, PTI and the effectortriggered immunity (ETI) activated by strain-specific effectors. Both PTI and ETI play roles in providing nonhost resistance of plant species against non-adaptive or nonhost pathogens. It is speculated that PTI and ETI play an increasingly major and a minor role, respectively, in conferring nonhost resistance as the evolutionary distance between the nonhost and the nonhost pathogen species widens [18]. Conversely, ETI and PTI play an increasingly major and a minor role, respectively, in expression of nonhost resistance as the evolutionary distance between the nonhost and nonhost pathogens reduces.

Soybean (Glycine max L. Merr.) is one of the most important oil seed crops, a major source of livestock feed and an important biodiesel crop. Unfortunately, soybean is also a host of many pathogens that cause several serious diseases resulting in an estimated annual yield loss of $\$ 2.26$ billion dollars [19]. In the United States, the estimated annual soybean yield losses just from the oomycete pathogen, $P$. sojae, have been valued to be over 300 million dollars [19]. Although various Rps (resistance to $P$. sojae) genes are utilized in generating Phytophthora resistant soybean cultivars [20,21], resistance conferred by these genes is effective only against a set of $P$. sojae races and is not durable. Partial resistance governed by quantitative trait loci (QTL) confers broadspectrum resistance against $P$. sojae races in soybean. However, the level of partial resistance is not adequate enough to prevent significant crop losses [22]. Thus, it is essential to identify and use NHR mechanisms to provide soybean with broad-spectrum and durable resistance against this pathogen. As a first step towards achieving this goal, we have applied a forward genetic approach to identify and map the Arabidopsis thaliana NHR gene, PSS1, which provides resistance against the oomycete pathogen $P$. sojae. PSS1 is also required for immunity of Arabidopsis against the fungal pathogen, Fusarium virguliforme that causes the sudden death syndrome (SDS) in soybean. 


\section{Results}

Arabidopsis pen1-1 mutant, but not nho1 mutant, is penetrated to single cells by the soybean pathogen $P$. sojae

Arabidopsis nho1 and pen1-1 mutants are defective in NHR mechanisms against the bacterial pathogen, Pseudomonas syringae pv. phaseolicola [5] and the powdery mildew fungus, Blumeria graminis f. sp. hordei [8], respectively. We investigated if the soybean pathogen $P$. sojae infects either of the two mutants. Ten-day-old seedlings grown in autoclaved double distilled water were inoculated with $P$. sojae zoospore suspensions and incubated for two days in the dark at $22^{\circ} \mathrm{C}$. The inoculated seedlings were then stained with trypan blue dye and observed under a light microscope [23]. The pathogen did not penetrate either the wild-type ecotype Columbia-0 (Col-0) or the nho1 mutant (Figures 1A and B). P. sojae however penetrated single cells in pen1-1 (Figure 1C). These results indicated that in the pen1-1 mutant, the pre-haustorial NHR against $P$. sojae is compromised.

\section{Identification of Phytophthora sojae susceptible (pss) putative mutants}

We mutagenized pen1-1, compromised in pre-invasive immunity against $P$. sojae, with ethyl methane sulfonate
(EMS) to identify mutants that are compromised in post-invasive immunity mechanisms. Over 3,500 $\mathrm{M}_{1}$ plants were planted and $\mathrm{M}_{2}$ seeds of these plants were harvested individually. Three hundred and seventy-nine randomly selected $\mathrm{M}_{2}$ families were grown to score for the chlorophyll mutants, a marker for determining the extent of EMS-induced mutation. About 5\% of the families segregated for albino plants (Additional file 1), which suggested that the mutant population contained sufficient random point mutations and was suitable for screening. Approximately $\geq 70$ seedlings of each $\mathrm{M}_{2}$ family were grown aseptically in 24-well microtiter plates in sterile water at $22^{\circ} \mathrm{C}$ for 10 days before inoculating with $P$. sojae zoospores. Following inoculation, seedlings were incubated for two days at $22^{\circ} \mathrm{C}$ in the dark, and then seedlings were stained with trypan blue for identifying putative mutants via staining of dead infected cells [23]. From screening 3,500 $\mathrm{M}_{2}$ families, we identified 30 putative mutants that were penetrated by $P$. sojae to multiple cells. The putative mutants were named as Phytophthora sojae susceptible 1 (pss1) through pss30. Subsequently, a detached leaf inoculation technique, previously reported for soybean, was applied in screening the putative mutants to identify the homozygous mutant plants [24]. We have applied a mapping approach in classifying these putative mutants. A homozygous mutant $\mathrm{M}_{4}$ family
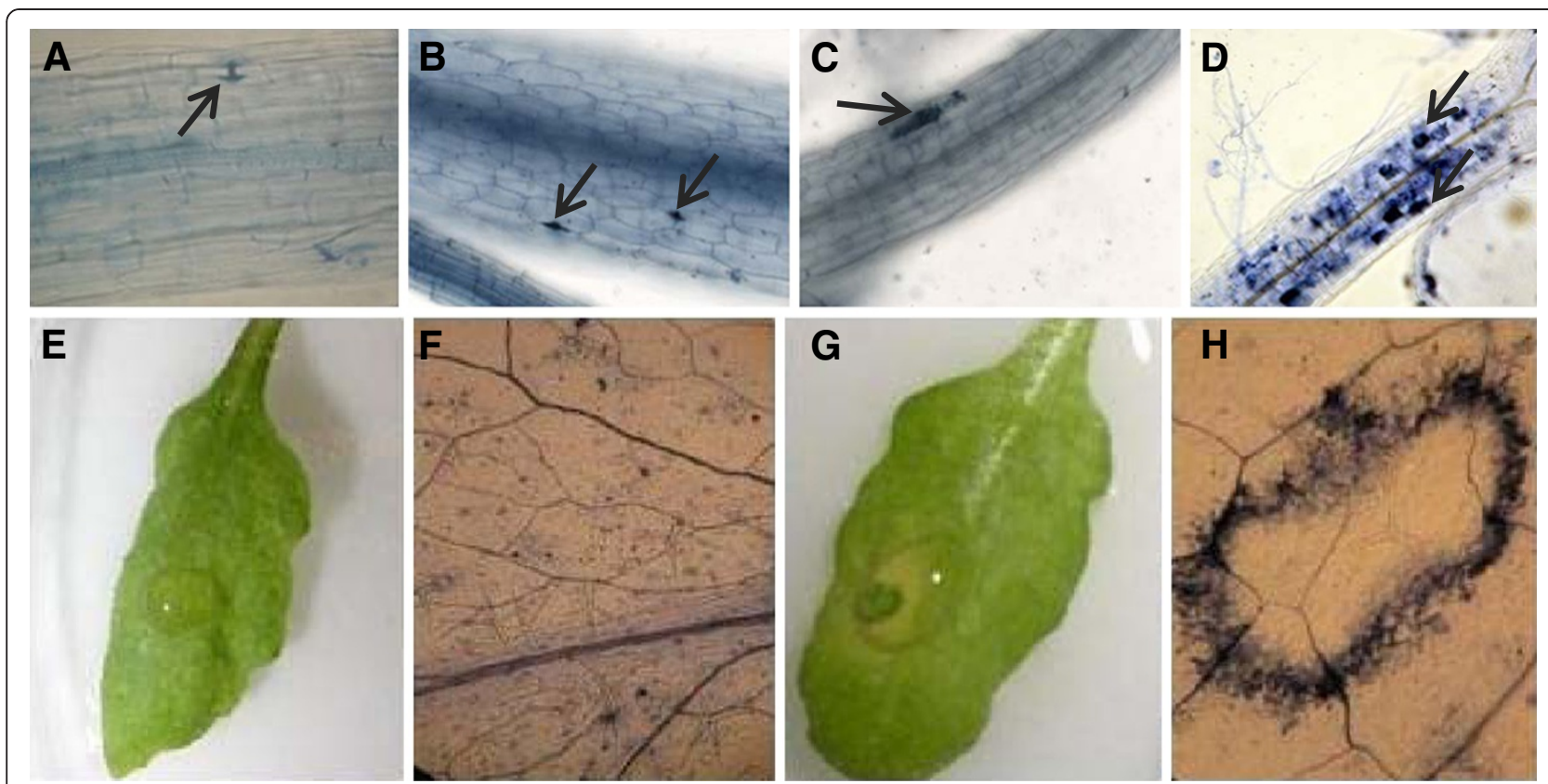

Figure 1 Identification of the pss 1 mutant $\mathbf{A}$, Columbia-0 and $\mathbf{B}$, nhol seedlings were not penetrated by $P$. sojae. $\mathbf{C}$, single cells of pen $1-1$ were penetrated by $P$. sojae and cell death occurred following penetration. D, The pss1 mutant showed penetration and colonization by $P$. sojae. Images shown in A, B, C and D were taken at 100X magnification. Arrows in A and B show failed attempts of penetration by germinating zoospores. Arrows in $C$ and $D$ show the cell death caused by penetrating hyphae. $\mathbf{E}$ and $\mathbf{F}$, macroscopic and microscopic responses of pen 1-1 following P. sojae infection; $\mathbf{G}$ and $\mathbf{H}$, macroscopic and microscopic responses of pss 1 leaf following $P$. sojae infection. Images of $\mathrm{F}$ and $\mathrm{H}$ were taken at 50X magnification. The photographs show representative results obtained from three independent experiments. Microscopic images of $A, B, C, D, F$ and $H$ were taken following staining of infected tissue samples with trypan blue.. 
$\left(0.2 \mathrm{~B}_{17} \mathrm{I}_{9}-24\right)$ of the putative mutant pss1 showing complete loss of both pre- and post-haustorial NHR against $P$. sojae was selected. In successive generations, the selected pss 1 mutant family was consistently infected by $P$. sojae. This mutant was phenotypically different from the pen1-1 because death in the mutant seedlings occurs in multiple cells as compared to in single cells in the pen1-1 mutant (Figure 1D, E, F, G, H). Although the $P$. sojae zoospores germinated and were able to form appresoria at the infection site, its growth was arrested immediately following germination on wild type Col-0 leaves. The pen1-1 mutant showed occasional death in single cells following $P$. sojae infection.

To determine the extent of $P$. sojae growth in infected tissues, detached pss 1 leaves were collected 6 hours post inoculation (hpi) with $P$. sojae zoospore suspensions or treatments with water droplets. Leaves were then stained with aniline blue and the ultraviolet epiflourescence was visualized using a Zeiss Axioplan II compound microscope [25]. Extensive colonization by the pathogen was observed in the pss1 mutant (Figure 2A). Aniline blue stains the callose deposition and papillae formation and can be used to visualize fungal structures such as runner hyphae [26,27]. Callose deposition and papillae formation have previously been used as markers for attempted penetration by fungal pathogen [7]. Following inoculation with $P$. sojae zoospores, pss1 leaves showed extensive callose deposition and papillae formation across the infected leaf tissue as compared to pen 1-1 and Col-0 (Figure 2A). Neither callose deposition nor papillae formation was detected in detached leaves that were treated with water droplets (Additional file 2A). At $6 \mathrm{hpi}$, extensive growth of the secondary hyphae was observed in $P$. sojae infected leaves of pss 1 but not that of Col-0 and pen1-1 (Figure 2A).

To determine if $P$. sojae became adapted to the Arabidopsis pss 1 mutant, we conducted microscopic study of the diseased lesions of the detached pss 1 leaves 7 days post-inoculation (dpi) with the zoospore suspensions of the oomycete (Figure 2B). We observed enhanced hyphal growth and formation of reproductive structures, sporangia and oogonia on pss1 leaves (Figure 2B, Additional file 2B). Thus, we conclude that a gene mutated in pss 1 is crucial for pre- and post-invasive nonhost immunity of Arabidopsis against the soybean pathogen, P. sojae. We named this gene PSS1.

\section{Arabidopsis ecotypes showed leakiness in their NHR responses to $P$. sojae}

Columbia-0 (Col-0) and Landsberg erecta (Ler) are the two most well characterized ecotypes of Arabidopsis thaliana for mapping and gene cloning experiments $[28,29]$. We investigated if the ecotype Ler was completely immune to $P$. sojae so that it could be crossed to pss1 for generating mapping populations. However, Ler showed leakiness in its immune response against $P$. sojae and a significant proportion (12.5\%) of the Ler seedlings were infected by $P$. sojae (Table 1 ). This result is not very surprising because the Arabidopsis ecotype L. erecta has recently been found to show susceptibility to another oomycete pathogen, Pythium irregulare [26]. We therefore inoculated $22 \mathrm{~A}$. thaliana ecotypes with $P$. sojae zoospores and discovered that ecotypes, Bensheim, Nossen-0 (No-0) and Niederzenz-0 (Nd-0) were completely immune to the pathogen (Table 1). We selected $\mathrm{Nd}-0$ for mapping experiments because it is morphologically similar to Col-0. Furthermore, a few molecular markers polymorphic between $\mathrm{Nd}-0$ and Col-0 were already available [30].

\section{PSS1 is required for nonhost resistance of Arabidopsis against $P$. sojae}

Forty-two $\mathrm{F}_{2: 3}$ families developed from the cross between pss 1 and $\mathrm{Nd}-0$ were evaluated for segregation of host responses to the pathogen infection. At least 24 progenies of each $F_{2}$ plants were scored for disease phenotypes. The segregation of alleles at the PSS1 locus among the $\mathrm{F}_{2: 3}$ families fit to the 1:2:1 genotypic ratio for a single gene model ( $p=0.81$; Table 2$)$. This observation suggested that PSS1 is a single gene with no apparent epistatic effect from PEN1.

In addition to these $42 \mathrm{~F}_{2: 3}$ families, we determined the phenotypes of additional families. In this experiment, only eight progenies per family were screened to identify the $\mathrm{F}_{2: 3}$ families that carry pss 1 in homozygous condition. To further confirm that PSS1 is a single gene with no epistatic effect from PEN1, we evaluated the segregation of the PEN1 alleles among $20 \mathrm{~F}_{2: 3}$ families, homozygous for the pss1 allele, using the dCAPS marker for PEN1 alleles [7]. PEN1 alleles segregated in a $1: 2: 1$ ratio $(p=0.67)$ among the 20 families, homozygous for the pss1 allele (Figure 3). This result suggested an independent segregation for the two genes. Among the 20 homozygous families for the pss1 allele, four were shown to carry the PEN1 allele in homozygous condition. If the PEN1 allele was epistatic to PSS1 and PSS1 were to encode only a post-invasive resistance mechanism, then the pen1-1 allele should have been in recessive homozygous condition among the pss 1 homozygous families. Thus, PSS1 encodes a new form of penetration resistance.

\section{Expression of $P$. sojae effector genes in pss1 during infection}

To determine the extent of $P$. sojae-gene expression, we selected two effector genes to conduct RT-PCR. It has been shown that $P$. sojae carries over 370 
candidate effector proteins containing N-terminal RXLR-dEER motifs [31]. We studied the expression of PsAvh223 and PsAvh224 [32] in pss1, pen1-1 and Col0 following inoculation with $P$. sojae. Both effector $P$. sojae genes were highly expressed in the pss1 mutant as compared to pen1-1 and Col-0 (Figure 4). This result indicates that the $P$. sojae colonized to a greater extent in pss 1 as compared that in pen1-1 or Col-0.
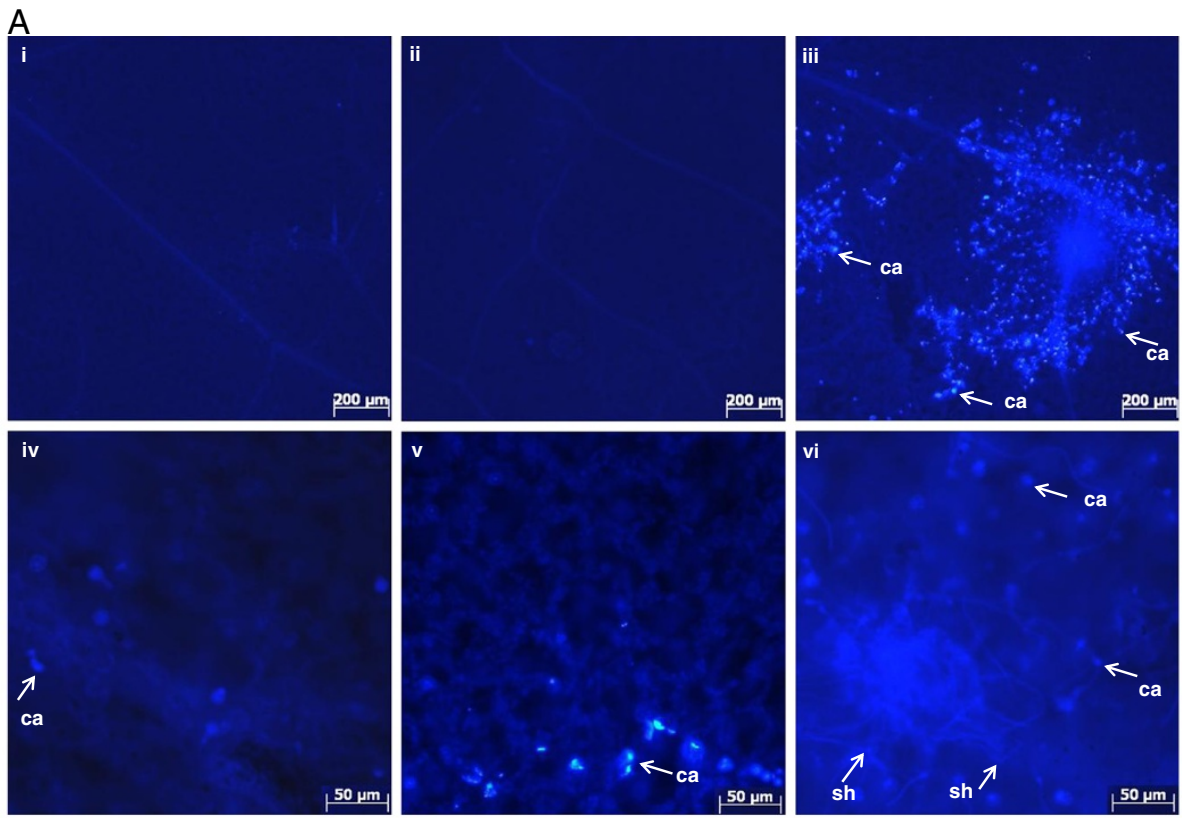

B
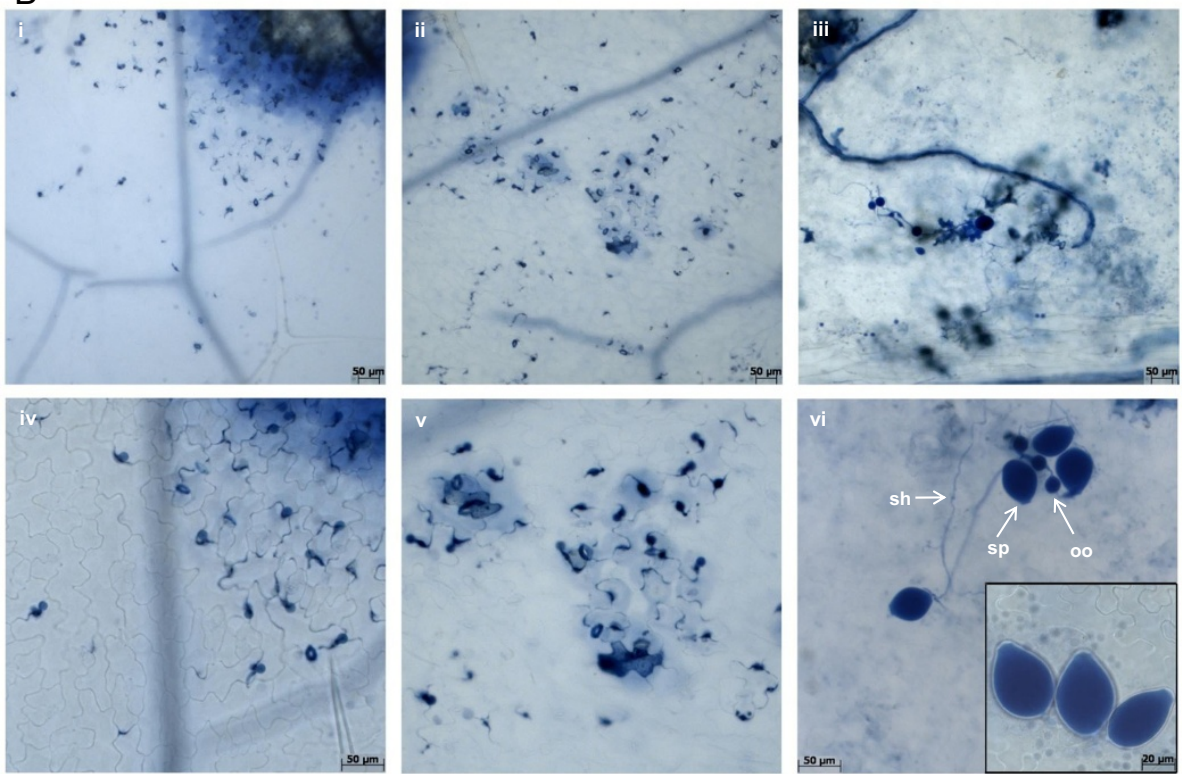

Figure 2 Responses of the pss 1 mutant following P. sojae infection. A, Leaves of 21 day old Col-0, pen 1-1 and pss 1 seedlings were inoculated with $P$. sojae zoospores and stained with aniline blue and visualized under a Zeiss Axioplan II compound microscope with ultraviolet epifluorescence [25]. (i) and (iv), Col-0; (ii) and (v), pen1-1; and (iii) and (vi), pss 1 leaves that were stained with aniline blue to detect callose deposition 6 hours post inoculation (hpi) with P. sojae by epifluorescence of the aniline blue. (i-iii), 50X magnification; and (iv-vi), 200X magnification. Arrows indicate sites of callose deposition (ca) and secondary hyphae (sh). The experiment was repeated twice with similar results. B, Leaves of 21 day old Col-0, pen1-1 and pss1 seedlings were inoculated with P. sojae zoospores and stained with trypan blue and visualized under a Zeiss Axioplan II compound microscope under bright field illumination [23]. (i) and (iv), Col-0; (ii) and (v), pen 1-1; and (iii) and (vi), pss1 leaves that were stained with trypan blue to detect cell death and fungal structures 7 days following inoculation with $P$. sojae zoospores. Arrows indicate reproductive structures, oogonia (oo), sporangia (sp) and secondary hyphae (sh), which were visible in infected pss 1 leaves. (i-iii), 100X magnification; and (iv-vi), 200X magnification. The experiment was repeated twice with similar results.. 
Table 1 Responses of Arabidopsis ecotypes to $P$. sojae

\begin{tabular}{|c|c|c|c|c|c|c|}
\hline \multicolumn{4}{|c|}{ Seedling Inoculation } & \multicolumn{3}{|c|}{ Leaf Inoculation } \\
\hline Ecotypes & ${ }^{1}$ Immune & ${ }^{2}$ Infected & $\%$ Infection & ${ }^{1}$ Immune & ${ }^{2}$ Infected & $\%$ Infection \\
\hline AUA/Rhon & 42 & 0 & 0.00 & - & - & - \\
\hline Bensheim & 45 & 0 & 0.00 & - & - & - \\
\hline Cape Verde-0 & 24 & 1 & 4.00 & 19 & 5 & 20.83 \\
\hline Catania & - & - & - & 21 & 3 & 12.50 \\
\hline Columbia-0 & 250 & 5 & 1.96 & 20 & 1 & 4.76 \\
\hline $\mathrm{Da}(1)$ & - & - & - & 17 & 7 & 29.17 \\
\hline Ellershausen-0 & - & - & - & 19 & 5 & 20.83 \\
\hline Estland & 19 & 2 & 9.52 & 14 & 4 & 22.22 \\
\hline Greenville-0 & 11 & 1 & 8.33 & - & - & - \\
\hline Isenberg & - & - & - & 14 & 7 & 33.33 \\
\hline Kaunas-0 & - & - & - & 20 & 4 & 16.67 \\
\hline Kendalville & 53 & 1 & 1.85 & - & - & - \\
\hline Koln-59 & - & - & - & 24 & 0 & 0.00 \\
\hline Lanark-0 & - & - & - & 10 & 8 & 44.44 \\
\hline Landsberg erecta & 348 & 15 & 4.13 & 28 & 4 & 12.50 \\
\hline Le Mans-2 & - & - & - & 19 & 5 & 20.83 \\
\hline Limeport & - & - & - & 20 & 4 & 16.67 \\
\hline Muhlen-0 & 29 & 0 & 0.00 & 20 & 4 & 16.67 \\
\hline Niederzenz-0 & 36 & 0 & 0.00 & 21 & 0 & 0.00 \\
\hline Nossen-0 & 38 & 0 & 0.00 & - & - & - \\
\hline Oystese-0 & - & - & - & 19 & 5 & 20.83 \\
\hline Poppelsdorf-0 & - & - & - & 20 & 4 & 16.67 \\
\hline RLD1 & 30 & 1 & 3.23 & - & - & - \\
\hline 596 & 37 & 1 & 2.63 & - & - & - \\
\hline
\end{tabular}

\section{Mapping of the PSS1 gene}

In order to map the PSS1 gene, we applied bulked segregant analysis (BSA) [33]. Four bulks of $P$. sojae susceptible plants each carrying 7-8 $\mathrm{F}_{2: 3}$ susceptible families and one bulk of $P$. sojae resistant plants containing two homozygous (PSS1PSS1) and six heterozygous (PSS1pss1) $\mathrm{F}_{2: 3}$ families were generated. These five bulks and Col-0 and $\mathrm{Nd}-0$ were included in BSA. We used sequence-based polymorphic (SBP) [34], SSLP and CAPS markers in conducting BSA.

Table 2 Segregation of Pss 1 alleles among the $F_{2: 3}$ families derived from a cross between the pss 1 mutant and the ecotype $\mathrm{Nd}-\mathrm{O}$

\begin{tabular}{lll}
\hline Genotype & Observed & Expected \\
\hline Homozygous resistant (PsS1Pss1) & 12 & 10.5 \\
\hline Heterozygous (Ps 1pss1) & 21 & 21 \\
\hline Homozygous susceptible (pss1pss1) & 9 & 10.5 \\
\hline Total & 42 & 42 \\
\hline $\boldsymbol{X}^{\mathbf{2}}$ value & 0.43 & \\
\hline $\boldsymbol{P}$-value & 0.81 & \\
\hline
\end{tabular}

The PSS1 region was putatively mapped to the south arm of chromosome 3 (Figure 5A). To develop a highdensity map of the PSS1 region, five SBP markers from this region were generated. SBP_20.71 marker showed a recombination event with the PSS1 locus in the $\mathrm{F}_{2: 3}$ family 93 suggesting that PSS1 is located south of this marker (Figure 5B). No recombination was observed between PSS1 and SBP_23.46 marker, located at the telomeric end of chromosome 3 (Figure $5 \mathrm{C}$ ). The physical distance between SBP_20.71 and SBP_23.46 is $2.75 \mathrm{Mb}$.

The Arabidopsis pss 1 mutant is infected by the fungal pathogen, Fusarium virguliforme, which causes sudden death syndrome in soybean

We investigated if PSS1 controls Arabidopsis NHR against the fungal pathogen, $F$. virguliforme that causes sudden death syndrome (SDS) in soybean. From the segregating materials used for mapping the PSS1 gene, we selected six $\mathrm{F}_{2: 3}$ families that were homozygous for either PSS1 or pss1 alleles (Additional file 3) and used these families in determining the role of PSS1 in NHR of Arabidopsis against F. virguliforme. Seedlings of the selected 


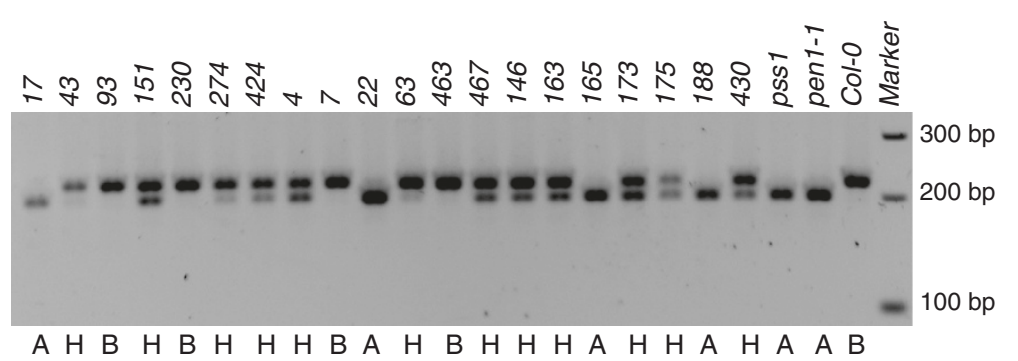

Figure 3 Segregation of PEN1 alleles among $20 \mathrm{~F}_{2: 3}$ families homozygous for pss 1. dCAPS marker based on SNP between PEN1 and pen 1-1 alleles was used to determine the genotypes for alleles of the PEN1 locus. Genotype A: homozygous for the pen 1-1 allele, B: homozygous for the PEN1 allele, $\mathrm{H}$ : heterozygous..

families were grown in 24-well microtiter plates for 10 days and then inoculated with $F$. virguliforme conidial spores. Infected seedlings were stained with trypan blue and observed under a light microscope (Figure 6A). Significant proportions of seedlings in six families carrying the pss 1 allele were infected by the fungal pathogen (Figure 6B). This result suggests that PSS1 is also essential for NHR against the soybean pathogen, F. virguliforme.

\section{PSS1 is not required for NHR of Arabidopsis against the non-adaptive pathogen Pseudomonas syringae pv. glycinea that causes bacterial blight in soybean}

We investigated if PSS1 is required for NHR of Arabidopsis against the bacterial pathogen, Pseudomonas syringae pv. glycinea $(P s g)$ that causes bacterial blight in soybean [35]. We inoculated the six $F_{2: 3}$ families homozygous for pss 1 and five $\mathrm{F}_{2: 3}$ families homozygous for the PSS1 allele with Psg (Figure 6C). We observed no association of PSS1 and pss 1 alleles with the colony forming units (cfu) of the bacterial pathogen. We classified the responses of the selected families into two broad groups, one with cfu comparable to those observed for Col-0 and $\mathrm{Nd}-0$; and the other one with five- or more-fold lesser cfu as compared to those observed in Col-0 and Nd-0. Surprisingly, pen1-1 consistently showed about 4-5-fold less bacterial growth as compared to that in Col-0 (Figure 6C). To determine if PEN1 is required for growth of Psg, we genotyped the selected susceptible and resistant $F_{2: 3}$ families for the PEN1 locus (Additional file 4). No association was observed between alleles at the PEN1 locus and the levels of Psg cfu. These results suggested that an unknown mutation in the pen1-1 genotype is most likely involved in enhancing resistance of Arabidopsis against Psg (Figure 6C) and the unknown gene could be a negative regulator of disease resistance.

\section{Discussion}

Transfer of NHR mechanisms across species may lead to development of broad-spectrum and durable resistance in economically important crop species. Identification of NHO1 and PEN genes established the molecular basis of NHR. It also suggested the feasibility of transferring single gene-encoded NHR across plant species for creating durable and broad-spectrum resistance [4,6-8].

Here we have described the Arabidopsis PSS1 locus that carries one of the nonhost resistance genes conferring immunity of Arabidopsis against two important soybean pathogens, $P$. sojae and F. virguliforme. Considering the disease phenotypes observed in detached leaves of pss1 as opposed to that in detached leaves of the pen1-1 mutant following P. sojae inoculation (Figures 1 and 2), the NHR mechanism governed by PSS1 is most likely important not only to provide penetration resistance, but also to confer necessary protection against further spread of the pathogen. pss1 supports secondary hyphal growth and sporulation of $P$. sojae (Figure 2). These observations suggest that PSS1 encodes a NHR defense mechanism that regulates

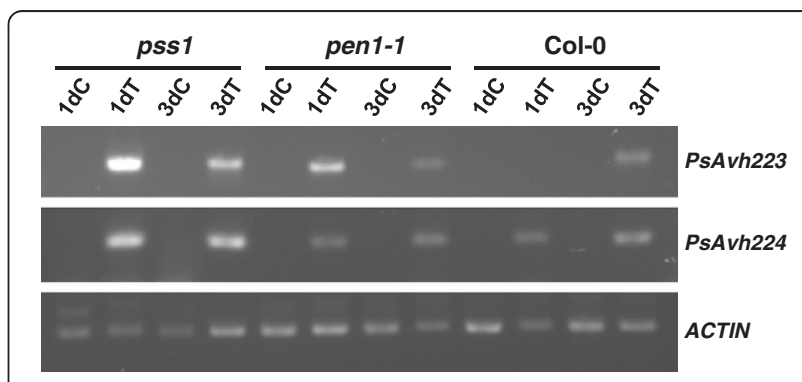

Figure 4 Induction of the effector genes in the Arabidopsis and P. sojae interactions. Expression levels of two P. sojae effector genes, PsAvh223 and PsAvh224, highly induced in the soybean-P. sojae interaction were determined in an RT-PCR experiment. Detached leaves of pss1, pen 1-1 and Col-0 were inoculated with $P$. sojae or treated with sterile water droplets. The cDNA samples were used to amplify the two effector genes of $P$. sojae and Arabidopsis actin gene. Enhanced expression of both effector genes were observed in psS 1 but not in pen 1-1 and Col-0. 1dC, 1 day post water droplet treatment of detached leaves; $3 \mathrm{dC}, 3$ days post water droplet treatment of detached leaves; $1 \mathrm{dT}, 1$ day post inoculation with $P$. sojae zoospores; $3 \mathrm{dT}, 3$ day post inoculation with $P$. sojae zoospores. Actin was used as an internal control.. 

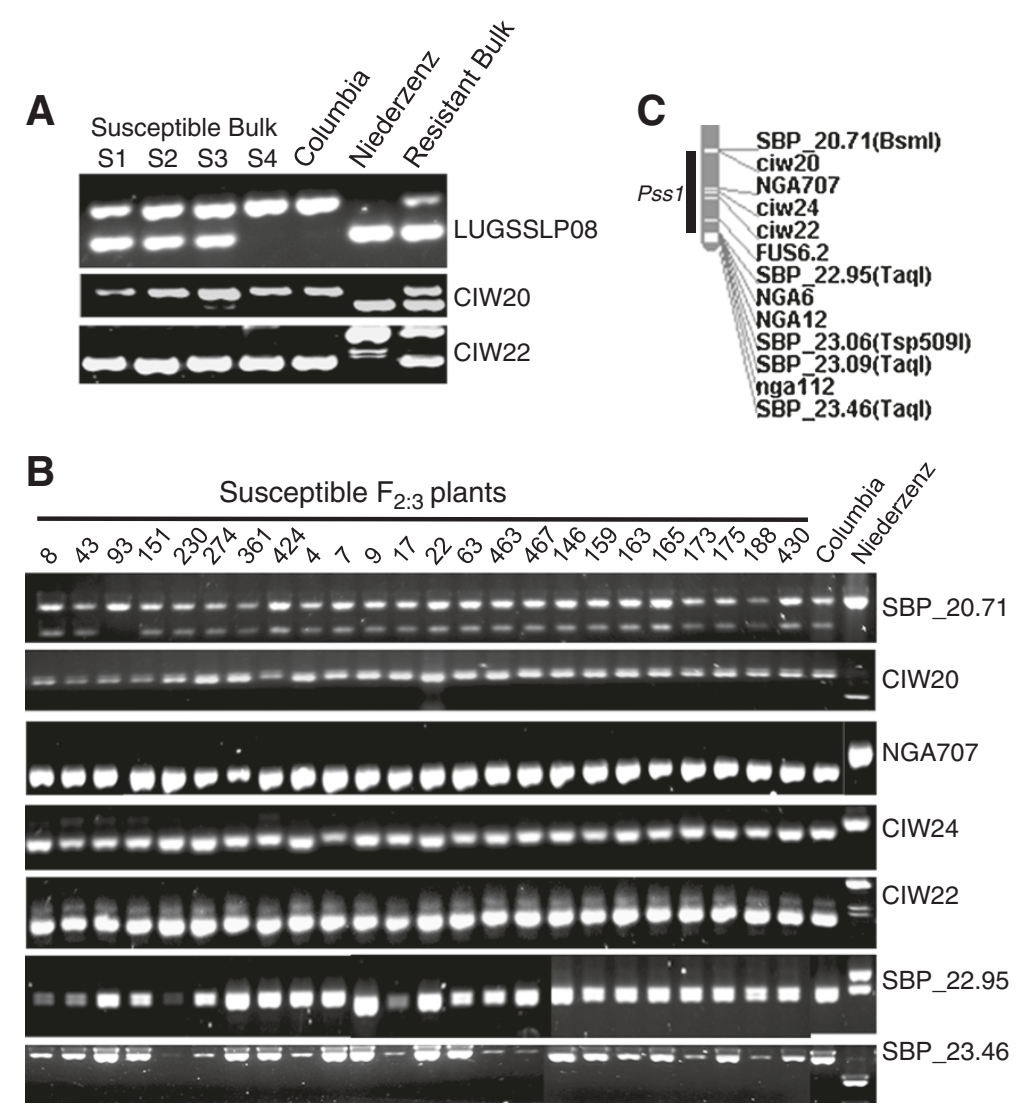

Figure 5 Molecular mapping of the PSS1 locus. A, Identification of SSLP markers linked to PSS1. Similar amplification patterns of SSLP markers CIW20 and CIW22 in susceptible bulks (S1, S2, S3 and S4) and Col-0 suggested that PSS1 is putatively linked to the two markers. Amplification patterns of a distantly mapped SSLP marker, LUGSSLP08 in the bulked DNA samples are shown as the control. B, Co-segregation of PSS1 with six molecular markers of the south arm of chromosome 3. Twenty-two susceptible $F_{2: 3}$ families except one, $F_{2: 3}$ family 93 , showed same amplification patterns as in Col-0 for these markers. F $2: 3$ family 93 showed recombination between PSS1 and SBP_20.71. C, Molecular map of the PSS1 region. Five SBP markers were developed for the PSS1 region that was mapped to the southern arm of chromosome 3.

both penetration and post-penetration resistance. It has been shown that the NHR mechanism at the post-haustorial stage is most important in sow thistle for providing resistance against a poorly adapted powdery mildew fungus, Golovinomyces cichoracearum UMSG1 [36]. Similar mechanism could also be important for NHR of Arabidopsis against the non-adapted oomycete pathogen, $P$. sojae.

Segregation data from a cross between pss 1 and Nd-0 revealed 1:2:1 genotypic segregation ratio for the alleles at the PSS1 locus (Table 2); and therefore, it is a single gene. Alleles at the PEN1 locus segregated independently of the alleles at the PSS1 locus (Figure 3). The P. sojae susceptible phenotype of the pss1 allele is manifested even in the presence of PEN1. Thus, PSS1 controls a novel defense mechanism for penetration resistance against the oomycete pathogen, $P$. sojae and the fungal pathogen, $F$. virguliforme. PEN genes have been shown to regulate two distinct NHR mechanisms that are involved in penetration resistance. Monogenic inheritance of PSS1 with no epistatic effect from PEN1 suggests that an additional Arabidopsis NHR mechanism is operative against penetration by oomycete and Fusarium pathogens. PSS1 is located in an approximately $2.75 \mathrm{Mb}$ region flanked by two sequence-based polymorphic markers, SBP_20.71 and the telomere-specific SBP_23.46 (Figure 5C). This region does not contain any characterized plant defense or disease resistance genes. Thus, most likely we have identified a novel nonhost resistance mechanism in Arabidopsis.

The important hallmarks of a successful adapted pathogen are its ability to establish feeding structures, derive nutrition from the host and finally to complete its lifecycle in the host plant [3]. Aniline blue staining has previously been used to show oomycete feeding structures such as runner hyphae [26]. We observed secondary hyphae even after 6 hpi suggesting that $P$. sojae is able to form feeding structures in pss1 leaves at a very early stage following inoculation (Figure 2A). Sporangia are specialized asexual reproductive structures of oomycetes which can either germinate into hyphae or release about 10-30 zoospores 

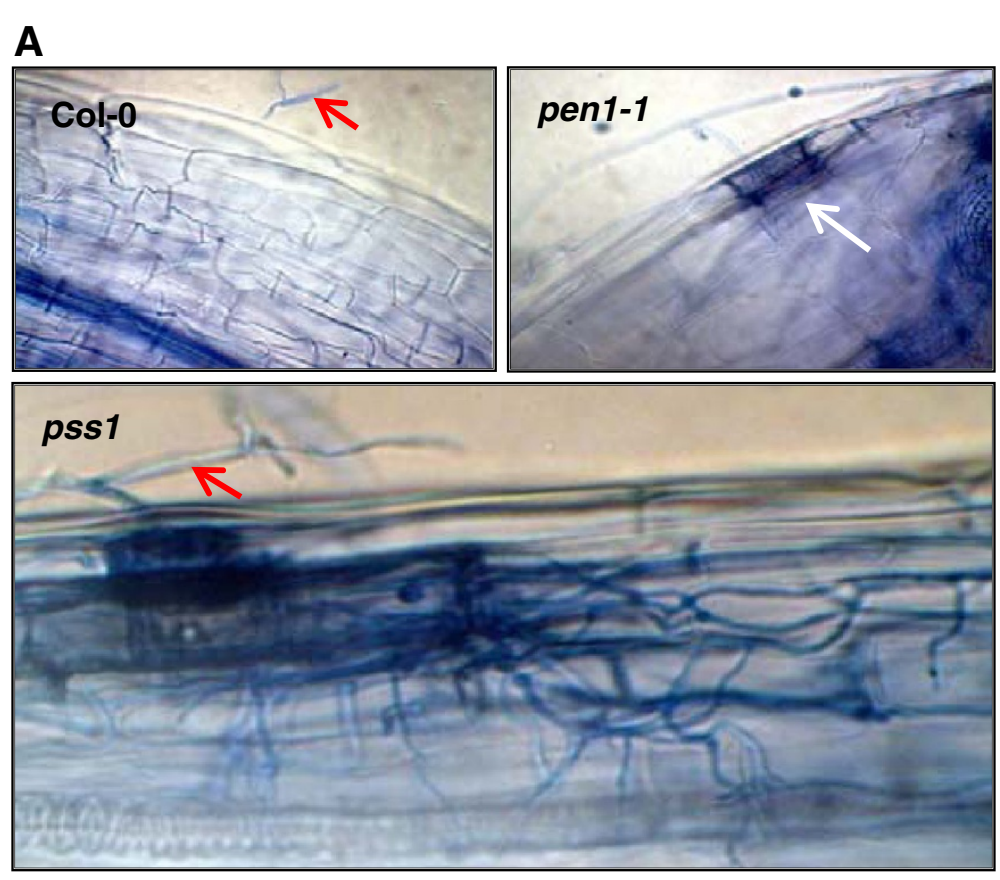

B

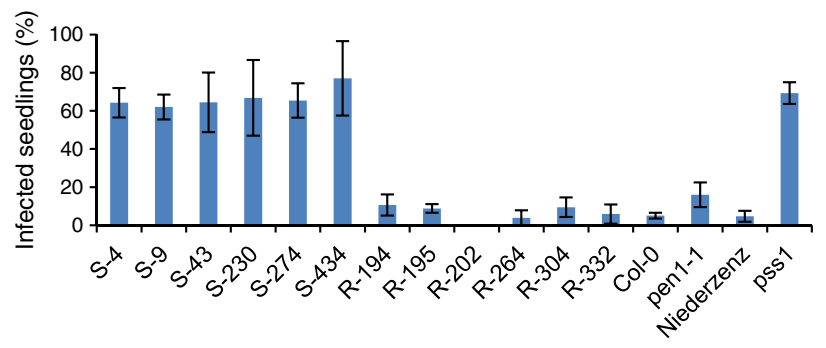

C

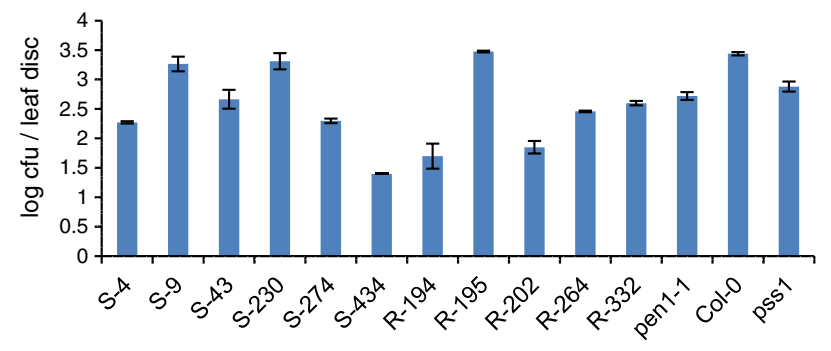

Figure 6 The pss 1 mutant was infected by fungal pathogen, F. virguliforme, but not by the bacterial pathogen, P. syringae pv. glycinea. A, Response of pss 1 to F. virguliforme infection. Cell death and spread of mycelia stained with trypan blue were observed in infected seedlings of pss 1 but not in those of Col-0 or pen 1-1 following inoculation with F. virguliforme conidial spores. Single cell penetration by $F$. virguliforme was observed in pen 1-1 but not in Col-0 seedlings. Red arrows show the germinating conidia. White arrow shows a dead infected cell. All images were taken 2 days post- inoculation and at 400X magnification. B, Responses of six P. sojae susceptible (pss1pss 1) (S-4 through S-434) and six resistant (PSS1PSS1) (R-194 through $\mathrm{R}-332$ ) $\mathrm{F}_{2: 3}$ families and the ps51 mutant to inoculation with F. virguliforme conidial spores are presented. Data are the mean of three independent experiments. Error bars indicate S.E. among experiments. C, Response of pss 1 to $P$. syringae pv. glycinea. Disease response in colony forming units (cfu) of six P. sojae susceptible (pss1pss 1) (S-4 through S-434) and five resistant (PSS1PSS1) (R-194 through R-332) $F_{2: 3}$ families and the pss 1 mutant 2 days following inoculation of intact leaves with P. syringae pv. glycinea are shown. Data are mean of three replications of a representative experiment. The experiment was repeated two times with similar results. Error bars indicate S.E. among experiments..

to complete the asexual life-cycle. The male and female reproductive structures, antheridia and oogonia, are fused to develop oospores and complete the sexual life [37].
P. sojae developed both sporangia and oogonia in infected pss1 leaves; and thus, completed its life cycle in this mutant (Figure 2B). In contrast, in pen1-1 leaves the pathogen 
was able to penetrate single cells, which die following penetration; while in the wild type Col-0 leaves, germinated $P$. sojae zoospores failed to penetrate host cells (Figure 2B).

Lack of epistasis of PEN1 on PSS1 (Figure 3), growth of secondary hyphae and rapid induction of effector genes in the pss 1 mutant, and most importantly completion of the $P$. sojae's life cycle in infected pss1 mutant leaves suggest that PSS1 encodes a novel NHR mechanism that regulates both pre- and post-invasive resistance of Arabidopsis against the nonhost pathogen. Transfer of this to soybean could play an important role in creating broad-spectrum disease resistant not only against $P$. sojae, but also $F$. virguliforme. It is also possible that PSS1 encoded resistance may be applicable to fighting diseases caused by oomycete pathogens in other crop species; such as potatoes and tomatoes.

It has been shown that lack of either of a functional pathway, the PEN1/SNAP33/VAMP721/722 or the indole- glucosinolates/metabolites pathway, involving the PEN2/PEN3 activity is sufficient to allow a nonadapted fungal pathogen to enter Arabidopsis mutant plants at a rate similar to that in an adapted host [38]. However, a complete loss of the subsequent post-invasion resistance mechanism encoded by plant defense genes PAD4 and SAG101 is necessary for a nonhost plant species to become a host for such non-adapted fungal pathogens [18]. In light of the critical role of the post-invasion genes as determinants of the nonhost status of Arabidopsis against non-adapted fungal pathogens, PSS1's role at both pre- and post-haustorial levels in conferring NHR of Arabidopsis against P. sojae is novel.

In vivo trans-specific gene silencing in Fusarium verticillioides from transgenic tobacco provides molecular evidence suggesting a possible short biotrophic phase in Fusarium species [39]. F. virguliforme has been considered to be semi-biotrophic fungus with its ability to feed on live host soybean cells [40]. Thus, most likely PSS1 may regulate the immunity against both hemibiotrophs, $P$. sojae and $F$. virguliforme, by using the same mechanism. The differing lifestyles of the two pathogens, $P$. sojae and F. virguliforme and the importance of PSS1 in providing nonhost resistance against both of these pathogens hints at a crucial role of this gene in broader nonhost resistance of the model plant, Arabidopsis.

\section{Conclusions}

Analyses of the segregants homozygous for alleles at both PEN1 and PSS1 loci revealed that PEN1 does not have any epistatic effect on the PSS1 function. The present study thus revealed a novel nonhost gene, PSS1, which confers immunity of Arabidopsis against two non-adaptive soybean pathogens, $P$. sojae and $F$. virguliforme. Responses of pss1 and pen1-1 to P. sojae invasion were distinct and PSS1 acts at both pre- and post-haustorial levels, while PEN1 acts at the pre-haustorial level. Identification and further characterization of the gene would provide us further insights about this new form of nonhost resistance against two non-adaptive soybean pathogens. This study thus laid the foundation for possible development of soybean germplasm with durable resistance against two serious pathogens.

\section{Methods}

\section{Mutagenesis of pen 1-1}

About 15,000 pen1-1 seeds were divided into three lots of $\sim 5,000$ seeds each. The three seed lots were then treated with $0.2 \%, 0.25 \%$, and $0.3 \%$ EMS solution, respectively, for $15 \mathrm{~h}$. The mutants were classified into three groups based on the concentration of EMS used for mutagenesis. Seeds were thoroughly washed 8 times in tap water and left in water on shaker for an additional hour. On an average, 1,000 seeds were sown on each flat (10$1 / 2 " \times 20-7 / 8 ")$. Two weeks later plants were transplanted to trays containing 32 pots. The $\mathrm{M}_{1}$ plants were selfed and seeds of 3,556 $\mathrm{M}_{2}$ families were individually harvested.

\section{Inoculation methods and disease scoring}

Two methods of inoculation were applied: i) seedling inoculation and ii) detached leaf inoculation. For the seedling inoculation, more than $70 \mathrm{~A}$. thaliana seeds of individual $\mathrm{M}_{2}$ families were sterilized in the wells of 24-well microtiter plates $\left(\operatorname{Costar}^{\circledR}\right.$ Corning Inc., Corning, NY) by first soaking in $70 \%$ ethanol for about 5 minutes and then washing with $50 \%$ Clorox bleach and $0.05 \%$ Triton X-100 for 10-15 minutes. The seeds were later rinsed four times with autoclaved water to remove any traces of bleach and/or ethanol. The seeds were then soaked aseptically in $300 \mu \mathrm{l}$ autoclaved, double distilled water and incubated at $4^{\circ} \mathrm{C}$ for $48 \mathrm{~h}$ followed by incubation at $22^{\circ} \mathrm{C}$ for 10 days under constant light $(100$ $\left.\mu \mathrm{E} / \mathrm{m}^{2} / \mathrm{s}\right)$. Seedlings were then inoculated with $300 \mu \mathrm{l}$ $P$. sojae zoospores race $25\left(10^{5}\right.$ zoospores $\left./ \mathrm{ml}\right)$. After two days of incubation at $22^{\circ} \mathrm{C}$ in the dark, the inoculated seedlings were stained with trypan blue and then destained with saturated chloral hydrate for $48 \mathrm{~h}$ [23]. Destained seedlings were mounted on a glass slide in 50\% glycerol and observed under a Zeiss microscope (Zeiss Incorporated, Thornwood, $\mathrm{NY}$ ) and seedlings showing enhanced cell death in multiple cells were scored as susceptible.

For the leaf inoculation, the seeds were sown on LC1 soil-less mixture (Sun Gro Horticulture, Bellevue, WA) under a $16 \mathrm{~h}$ light $/ 8 \mathrm{~h}$ dark regime at $21^{\circ} \mathrm{C}$ with approximately $60 \%$ relative humidity. The light intensity was maintained at $120-150 \mu \mathrm{E} / \mathrm{m}^{2} / \mathrm{s}$ [41]. Ten days after sowing, the seedlings were transplanted into a 
new LC1 mixture. The newly transplanted seedlings were covered with humidity domes for two days and thereafter watered every fourth day. A fertilizer mixture of $15: 15: 15:: \mathrm{N}: \mathrm{P}: \mathrm{K}(1 \%$ concentration $\mathrm{v} / \mathrm{v})$ was applied to the seedlings seven days after transplantation.

Three leaves (leaf \# 4, 5 and 6 from the apex) were detached from 21-day old plants and placed on moist Whatman filter papers, in Petri dishes. Each leaf was then inoculated with $10 \mu \mathrm{l}$ of $P$. sojae zoospore suspensions $\left(10^{5} / \mathrm{ml}\right)$. The Petri dishes, following closing the lids, were incubated under constant light $\left(50 \mu \mathrm{E} / \mathrm{m}^{2} / \mathrm{s}\right)$ at $22^{\circ} \mathrm{C}$. The inoculated plants were scored 48 and $72 \mathrm{~h}$ post inoculation (hpi) for resistant and susceptible host responses. In some experiments, 10- $\mu$ l droplets of autoclaved double distilled water were placed on the surface of detached leaves as a negative control.

\section{Microscopic evaluations}

Leaves of 21-day old Arabidopsis wild type Col-0, pen11 and pss 1 mutant plants were inoculated with $P$. sojae spores $\left(1.0 \times 10^{5}\right.$ spores $\left./ \mathrm{ml}\right)$ and stained with trypan blue 7 days post inoculation (dpi) [23] and with aniline blue dye at 6 hours post inoculation (hpi) [25]. The stained leaves were mounted in saturated chloral hydrate for trypan blue dye [23] or in $70 \%$ glycerol and 30\% aniline blue solution (0.01\%) for aniline blue dye [25]. Stained images were examined using a Zeiss Axioplan II compound microscope equipped with AxioCam color digital camera.

\section{DNA preparation, PCR and BSA}

Arabidopsis genomic DNA was extracted by CTAB method [42]. Young inflorescence or a rosette leaf was selected for DNA extraction. Equal amount $(10 \mu \mathrm{g})$ of DNA from individual $F_{2: 3}$ families were mixed to obtain bulk DNA samples. The final DNA concentration of these bulk DNA samples for PCR was $20 \mathrm{ng} / \mu \mathrm{l}$. The PCR reaction mixtures contained $2 \mathrm{mM} \mathrm{MgCl}$ (Bioline, Taunton, MA), $0.25 \mu \mathrm{M}$ each of forward and reverse primer (Integrated DNA Technologies, Inc., Coralville, Iowa), $2 \mu \mathrm{M}$ dNTPs and $0.5 \mathrm{U}$ Choice Taq polymerase (Denville Scientific, Inc., Metuchen, NJ). For SSLP markers, PCR was conducted at $94^{\circ} \mathrm{C}$ for $2 \mathrm{~min}$, and then 40

Table 3 Primers used in the RT-PCR experiment

\begin{tabular}{lll}
\hline Gene & 'Primer & Amplicon \\
\hline PsAvh223 & F:GGCCACCCACACACCCCTCCCTCCCGTC & 237 \\
\hline & R:CGGCGTCCTCGGCCTCGTCGTCTAG & \\
\hline PsAvh224 & F:GCGCGGCCTCGAGTCCTTCTTCGTG & 355 \\
\hline & R:CCTCCCTCCCGTCCGCTACAGTCATG & \\
\hline AtActin & F:GGCGATGAAGCTCAATCCAAACG & 491 \\
\hline \multicolumn{3}{l}{ R:GGTCACGACCAGCAAGATCAAGACG } \\
\hline
\end{tabular}

${ }^{1}$ Primers: $F$, forward primer; $R$, reverse primer cycles of $94^{\circ} \mathrm{C}$ for $30 \mathrm{~s}, 55^{\circ} \mathrm{C}$ for $30 \mathrm{~s}$ and $72^{\circ} \mathrm{C}$ for $30 \mathrm{~s}$. Finally, the mixture was incubated at $72^{\circ} \mathrm{C}$ for $10 \mathrm{~min}$. For the CAPS markers, PCR was conducted at $94^{\circ} \mathrm{C}$ for $2 \mathrm{~min}$, and then five cycles of $94^{\circ} \mathrm{C}$ for $30 \mathrm{~s}$ followed by decreasing annealing temperatures from $55^{\circ} \mathrm{C}$ to $50^{\circ} \mathrm{C}$

\section{Table 4 List of CAPS markers polymorphic between} Arabidopsis ecotypes $\mathrm{Col}-\mathrm{O}$ and $\mathrm{Nd}-\mathrm{O}$

\begin{tabular}{|c|c|c|}
\hline $\begin{array}{l}\text { CAPS } \\
\text { marker }\end{array}$ & $\begin{array}{l}{ }^{1} \text { Restriction } \\
\text { enzyme }\end{array}$ & ${ }^{2}$ Primers \\
\hline \multirow[t]{2}{*}{$1 \mathrm{H} 1 \mathrm{~L}-1.6$} & \multirow[t]{2}{*}{ Rsa I, Tsp509l } & F:CTAGAGCTTGAAAGTTGATG \\
\hline & & R:TTGAGTCCTTCTTGTCTG \\
\hline \multirow[t]{2}{*}{ 20B4L-1.6 } & \multirow[t]{2}{*}{ Ddel } & F:CTAAGATGGGAATGTTGG \\
\hline & & R:GAACTCATTGTATGGACC \\
\hline \multirow[t]{2}{*}{ 40E1T7 } & \multirow[t]{2}{*}{ AcCl } & F:GGTCCACTITGATTCAAGAT \\
\hline & & R:GCAAGCGATAGAACATAACG \\
\hline \multirow[t]{2}{*}{$\overline{A F 2}$} & \multirow[t]{2}{*}{ Ddel } & F:TCGTCGTITTGTTTCCTITTCTTA \\
\hline & & R:CCATTCATTTAGGCCCCGACTITC \\
\hline \multirow[t]{2}{*}{ B9-1.8 } & \multirow[t]{2}{*}{ Taql } & F:CATCTGCAACATCTTCCCCAG \\
\hline & & R:CGTATCCGCATTTCTTCACTGC \\
\hline \multirow[t]{2}{*}{ CAT } & \multirow[t]{2}{*}{ Taql, Tsp509l } & $\begin{array}{l}\text { F: } \\
\text { GACCAGTAAGAGATCCAGATACTGCG }\end{array}$ \\
\hline & & R:CACAGTCATGCGACTCAAGACTTG \\
\hline \multirow[t]{2}{*}{ ER } & \multirow[t]{2}{*}{ Ddel } & F:GAGTTTATTCTGTGCCAAGTCCCTG \\
\hline & & R:CTAATGTAGTGATCTGCGAGGTAATC \\
\hline \multirow[t]{2}{*}{ G4026 } & \multirow[t]{2}{*}{ Taql, Rsal } & F:GTACGGTTCTTCTTCCCTTA \\
\hline & & R:GGGGTCAGTTACATTACTAGC \\
\hline \multirow[t]{2}{*}{ G4711 } & \multirow[t]{2}{*}{ Ddel } & F:CCTGTGAAAAACGACGTGCAGTTTC \\
\hline & & R:ACCAAATCTTCGTGGGGCTCAGCAG \\
\hline \multirow[t]{2}{*}{$\overline{\text { GPA1.1 }}$} & \multirow[t]{2}{*}{ Tsp5091 } & F:ATTCCTTGGTCTCCATCATC \\
\hline & & R:GGGATTGATGAAGGAGAAC \\
\hline \multirow[t]{2}{*}{ JM411 } & \multirow[t]{2}{*}{ Ddel } & F:GCGAACCACTAAGAACTA \\
\hline & & R:CTCGACTTTGCCAAGGAT \\
\hline \multirow[t]{2}{*}{ LFY3 } & \multirow[t]{2}{*}{ Rsal } & F:GACGGCGTCTAGAAGATTC \\
\hline & & R:TAACTTATCGGGCTTCTGC \\
\hline \multirow[t]{2}{*}{ MI342 } & \multirow[t]{2}{*}{ Tsp509l } & F:GAAGTACAGCGGCTCAAAAAGAAG \\
\hline & & R:TTGCTGCCATGTAATACCTAAGTG \\
\hline \multirow[t]{2}{*}{ M555 } & \multirow[t]{2}{*}{ AcCl } & F:CCTITAATTAGTTATCAAATC \\
\hline & & R:CTCTTGAATTATTAAGTTGACTAG \\
\hline M59 & Rsal, Tsp509l & F:GTGCATGATATTGATGTACGC \\
\hline & & R:GAATGACATGAACACTTACACC \\
\hline MBK23A & Taql & F:GATGATTAGGCGCAAAATTGAG \\
\hline & & R:ATTACCAGCCTGGCTTCAGG \\
\hline PAl1.1 & Taql, Rsal, Tsp509l & F:GATCCTAAGGTATTGATATGATG \\
\hline & & R:GGTACAATTGATCTTCACTATAG \\
\hline T20D161 & Taql, Rsal, Tsp509l & F:CGTATTTGCTGATTCATGAGC \\
\hline & & R:ATGGTTTACACTTGACAGAGC \\
\hline T6P5-4.8 & Rsal & F:TGAAAGACACCTGGGATAGGC \\
\hline & & R:CCAACTITCGGGTCGGTTCC \\
\hline
\end{tabular}

${ }^{1}$ Restriction endonucleases used for individual CAPS markers are shown. ${ }^{2}$ Primers: $F$, forward primer; $R$, reverse primer 


\begin{tabular}{|c|c|c|c|}
\hline Name & ${ }^{1}$ Primer & ${ }^{2}$ Enzyme & $\begin{array}{l}\text { AmpliconSize } \\
\text { (bp) }\end{array}$ \\
\hline SBP_22.95 & $\begin{array}{l}\text { F: GGAGGTTCCGTTACTC } \\
\text { TTACTG R: CCACCGGAA } \\
\text { GACGACGACTCTTC }\end{array}$ & Rsal & 309 \\
\hline SBP_22.98 & $\begin{array}{l}\text { F: CGACGTCACACTCTCC } \\
\text { GTTA R: CCGATGATGGA } \\
\text { GAAGGAAAA }\end{array}$ & Taql & 230 \\
\hline$\overline{\text { SBP_23.06 }}$ & $\begin{array}{l}\text { F: AAATTGGGGACACCA } \\
\text { ACAAA R: GGTCCTCCTG } \\
\text { GGAGAAAGAT }\end{array}$ & Tsp509| & 180 \\
\hline SBP_23.09 & $\begin{array}{l}\text { F: TCGAATGATCCTTTCC } \\
\text { TTCA R: GCTITTGCGA } \\
\text { AAATGGGATA }\end{array}$ & Taql & 235 \\
\hline SBP_23.46 & $\begin{array}{l}\text { F: GACCAAATGTCTCTGA } \\
\text { GATGTTC R: ACCCAAGG } \\
\text { CGGTGTTGGCGAAAG }\end{array}$ & Taql & 520 \\
\hline
\end{tabular}

${ }^{1}$ Primers: $F$, forward primer; $R$, reverse primer. ${ }^{2}$ Restriction endonucleases used for individual CAPS markers are shown

$\left(-1^{\circ} \mathrm{C} /\right.$ cycle $)$ and $72^{\circ} \mathrm{C}$ for $1 \mathrm{~min}$. Then 40 cycles of $94^{\circ} \mathrm{C}$ for $30 \mathrm{~s}, 50^{\circ} \mathrm{C}$ for $30 \mathrm{~s}$, and $72^{\circ} \mathrm{C}$ for $1 \mathrm{~min}$ were conducted. Finally, the reaction mixture was incubated at $72^{\circ} \mathrm{C}$ for 10 minutes. PCR was carried out in PTC-100 Programmable Thermal Controllers (MJ Research Inc.). The amplified products were resolved on a $4 \%$ agarose gel by running at $8 \mathrm{~V} / \mathrm{cm}$. The ethidium bromide stained PCR products were visualized following illumination with UV light.

\section{RNA isolation and RT-PCR experiments}

Total RNA was isolated from leaf tissues using the TRIzol $^{\circledR}$ reagent according to the manufacturer's instructions (Invitrogen, Inc., Carlsbad, CA). RNA samples were treated with DNase I (Invitrogen, Inc., Carlsbad, CA) to eliminate any DNA contamination [43]. cDNAs were prepared according to manufacturer's recommendations (Invitrogen, Inc., Carlsbad, CA). PsAvh223, PsAvh224 and AtACTIN-specific primers (Table 3) were used to PCR amplify cDNA fragments from these samples. RT-PCR was conducted for the above genes using the cDNAs prepared from infected leaves at $1 \mathrm{~d}$ and $3 \mathrm{~d}$ post inoculation or treatment with water droplets. The following program was used to conduct PCR; $94^{\circ} \mathrm{C} 3 \mathrm{~min}$ and 35 cycles of $94^{\circ} \mathrm{C}$ for $30 \mathrm{sec}$, $60^{\circ} \mathrm{C}$ or $55^{\circ} \mathrm{C}$ and $72^{\circ} \mathrm{C}$ for $1 \mathrm{~min}$ followed by $72^{\circ} \mathrm{C}$ for $10 \mathrm{~min}$. The transcripts of AtACTIN were simultaneously amplified for each set of RT-PCR reaction to show the possible variations in starting RNA amounts of different samples.

\section{Molecular markers}

Sequences of primers for SSLP markers were obtained from The Arabidopsis Information Resource (TAIR) database (http://www.arabidopsis.org). SSLP markers, polymorphic between $\mathrm{Col}-\mathrm{O}$ and $\mathrm{Nd}-0$, were selected to cover the entire genome with a density of one SSLP marker/2 Mb DNA. For the SSLP-thin regions, CAPS and SBP markers were designed [34]. The primers for the CAPS are presented in Table 4 and that for the SBP markers are presented in Table 5.

\section{Seedling inoculation with $F$. virguliforme}

For inoculation of $\mathrm{F}_{2: 3}$ families with $F$. virguliforme, more than 70 seedlings of each family were grown in 24-well microtiter plates $\left(\operatorname{Costar}^{\circledR}\right.$ Corning Inc., Corning, NY) as described earlier. The seedlings of individual family were then inoculated with about $300 \mu \mathrm{l} F$. virguliforme spores $\left(10^{6}\right.$ spores $\left./ \mathrm{ml}\right)$ and incubated in the dark for $48 \mathrm{~h}$. The inoculated seedlings were then stained with trypan blue dye as previously described and observed under a microscope (Zeiss Inc., Thornwood, NY). Seedlings showing enhanced cell death in multiple cells were scored as susceptible.

\section{Leaf inoculation of $F_{2: 3}$ with the bacterial pathogen, $P$. syringae pv. glycinea}

For leaf inoculation of $\mathrm{F}_{2: 3}$ with $P$. syringae pv. glycinea, Arabidopsis plants were grown in a $10 \mathrm{~h}$ light/14 h dark period at $21^{\circ} \mathrm{C}$ under light intensity of $100-120 \mu \mathrm{mol} /$ $\mathrm{cm}^{2} / \mathrm{sec}$. P. syringae pv. glycinea was grown on King's B medium containing rifampicin $(100 \mu \mathrm{g} / \mathrm{ml})$ at $28^{\circ} \mathrm{C}$. For liquid culture, bacteria were grown in liquid King's B medium without rifampicin at $25^{\circ} \mathrm{C}$ for $24 \mathrm{~h}$. Four-week old plants were leaf inoculated with bacterial suspensions with $0.10 \mathrm{OD}_{600 \mathrm{~nm}}\left(\sim 2 \times 10^{6} \mathrm{cfu} / \mathrm{ml}\right)$ diluted in 10 $\mathrm{mM} \mathrm{MgCl} 2$ solution [44]. Four leaves of each plant were inoculated on the abaxial side with $50 \mu \mathrm{l}$ bacterial suspensions using the blunt end of a $1 \mathrm{ml}$ syringe (BD, Franklin Lakes, NJ). Plants were then covered with a humidity dome until samples were harvested for plating. 1 $\mathrm{cm}$ diameter leaf discs from each inoculated leaf samples were harvested at 0 and 3 days post-inoculation. Leaf discs of eight leaves from two plants were pooled to make one replication and three biological replications were performed. Serial dilutions of the extracts from leaf disc samples were plated on King's B medium containing rifampicin. Colony forming units (cfu) were counted 2 days following plating.

\section{Additional files}

Additional file 1: EMS mutants created in Arabidopsis thaliana pen 1-1 mutants showed chlorophyll-lacking mutants among $5 \%$ of the $\mathbf{M}_{\mathbf{2}: 3}$ families. The albino seedlings are shown with arrows.

Additional file 2: A: Autoflourescene of pss 1 mutant leaf. Detached leaves of 21-day old seedlings of the pss 1 mutant were mock inoculated with sterile water and stained with aniline blue and observed under ultraviolet epiflourescence 6 hours post inoculation. The image was taken at 50X magnification. The experiment was repeated three times with 
similar results. B: The pss1 mutant is a host for soybean oomycete pathogen, $P$. sojae. Detached leaves of pss 1 mutant were inoculated with P. sojae zoospores $\left(10^{5}\right.$ spores $/ \mathrm{ml}$.) and stained with trypan blue dye 7 days post inoculation (dpi). Formation of sexual female reproductive structures, oogonia (oo) and asexual reproductive structures, sporangia (sp) indicate that the pathogen is able to complete its life cycle on the host pss1 mutant leaves, thus signifying a complete breakdown of Arabidopsis nonhost resistance in this mutant. Numbers indicate the approximate size of the reproductive structures, which is in close agreement with the average size of the reproductive structures of the Phytophthora genus [45].

Additional file 3: Identification of $F_{2: 3}$ families homozygous for alleles at the PSS1 locus. A, Inoculation of a 10 day old pss 1 seedling with $P$. sojae spores followed by staining with trypan blue dye showed extensive hyphal growth and subsequent cell death. Image (100X magnification) was taken at $2 \mathrm{dpi}$. B, The indicated section of $\mathrm{A}$ at a higher magnification. $\mathbf{C}$, Reponses of 10-day old seedlings of six $\mathrm{F}_{2: 3}$ families, homozygous for the pss1 allele (S-4 through $\mathrm{S}-434$ ), and six $\mathrm{F}_{2: 3}$ families, homozygous for the PSS1 allele (R-194 through R-332), were inoculated with P. sojae zoospores. Data are mean of percent seedlings infected from three independent experiments. Error bars indicate standard error (S.E.) among experiments.

Additional file 4: Genotype of six $P$. sojae susceptible (pss1pss1) (S-4 through S-434) and five resistant (PSS1PSS1) (R-194 through R-332) $\mathrm{F}_{2: 3}$ families and the pss 1 mutant for the PEN1 alleles. A homozygous for pen 1-1, B, homozygous for PEN1; H, heterozygous.

\section{Competing interests}

The authors declare that they have no competing interests.

\section{Authors' contributions}

$\mathrm{RS}, \mathrm{BBS}, \mathrm{MX}$ and DS conducted the experimental work. RS and BBS wrote the first draft and contributed to writing the subsequent drafts of the manuscript. MKB conceived the research, designed the experiments and wrote the final draft of the manuscript. All authors read and approved the manuscript.

\section{Acknowledgements}

We thank Drs. Paul Schulze-Lefert and Jianmin Zhou for providing the seeds of pen 1-1and nho 1 mutants, respectively. We thank Dr. Coralie Lashbrook for providing seeds of Arabidopsis thaliana ecotypes. We thank Drs. Steve Rodermel and Yanhai Yin for providing primers for some of the SSLP and CAPS markers, respectively. We thank Dr. Jack Horner, Randall Den Adel and Ms. Tracey Pepper of the microscopy and nanoimaging facility at lowa State University for assisting us with microscopic studies. This work was supported by a grant from the Consortium for Plant Biotechnology Research (CPBR) and lowa Soybean Association.

\section{Author details}

'Department of Agronomy, lowa State University, Ames, IA 50011, USA. ${ }^{2}$ Molecular Cellular and Developmental Biology Interdepartmental Graduate program, lowa State University, Ames, IA 50011, USA. ${ }^{3}$ Department of Plant and Microbial Biology, UC Berkeley, Berkeley, CA 94720, USA. ${ }^{4}$ Biology Department, University of Wisconsin, Stevens Point, Wisconsin 54481, USA.

Received: 18 December 2011 Accepted: 23 May 2012

Published: 13 June 2012

\section{References}

1. Heath MC: Implications of nonhost resistance for understanding host-parasite interactions. In Genetic Basis of Biochemical Mechanisms of Plant Disease: APS Press; 1985.

2. Heath MC: The role of gene-for-gene interactions in the determination of host species specificity. Phytopathology 1991, 81:127-130.

3. Thordal-Christensen $\mathrm{H}$ : Fresh insights into processes of nonhost resistance. Curr Opin Plant Biol 2003, 6(4):351-357.

4. Kang L, Li J, Zhao T, Xiao F, Tang X, Thilmony R, He S, Zhou JM: Interplay of the Arabidopsis nonhost resistance gene $\mathrm{NHO1}$ with bacterial virulence. Proc Natl Acad Sci USA 2003, 100(6):3519-3524.
5. Lu M, Tang X, Zhou J-M: Arabidopsis NHO1 is required for general resistance against Pseudomonas bacteria. Plant Cell 2001, 13(2):437-447.

6. Lipka V, Dittgen J, Bednarek P, Bhat R, Wiermer M, Stein M, Landtag J, Brandt W, Rosahl S, Scheel D, et al: Pre- and postinvasion defenses both contribute to nonhost resistance in Arabidopsis. Science 2005, 310 (5751):1180-1183.

7. Stein M, Dittgen J, Sanchez-Rodriguez C, Hou B-H, Molina A, Schulze-Lefert P, Lipka V, Somerville S: Arabidopsis PEN3/PDR8, an ATP binding cassette transporter, contributes to nonhost resistance to inappropriate pathogens that enter by direct penetration. Plant Cell 2006, 18:731-746.

8. Collins NC, Thordal-Christensen H, Lipka V, Bau S, Kombrink E, Qiu J-L, Huckelhoven R, Stein M, Freialdenhoven A, Somerville SC, et al: SNAREprotein-mediated disease resistance at the plant cell wall. Nature 2003, 425(6961):973-977.

9. Ellis J: Insights into nonhost disease resistance: Can they assist disease control in agriculture? Plant Cell 2006, 18(3):523-528.

10. Lipka U, Fuchs R, Lipka V: Arabidopsis non-host resistance to powdery mildews. Curr Opin Plant Biol 2008, 11(4):404-411.

11. Glazebrook J: Contrasting mechanisms of defense against biotrophic and necrotrophic pathogens. Annu Rev Phytopathol 2005, 43(1):205-227.

12. Mellersh DG, Heath MC: Plasma membrane-cell wall adhesion is required for expression of plant defense responses during fungal penetration. Plant Cell 2001, 13(2):413-424.

13. Loehrer M, Langenbach C, Goellner K, Conrath U, Schaffrath U: Characterization of nonhost resistance of Arabidopsis to the Asian soybean rust. Mol Plant Microbe Interact 2008, 21(11):1421-1430.

14. Jones JDG, Dangl JL: The plant immune system. Nature 2006, 444(7117):323-329.

15. Schwessinger B, Zipfel C: News from the frontline: recent insights into PAMPtriggered immunity in plants. Curr Opin Plant Biol 2008, 11(4):389-395.

16. Mittler R, Herr EH, Orvar BL, van Camp W, Willekens H, Inze D, Ellis BE: Transgenic tobacco plants with reduced capability to detoxify reactive oxygen intermediates are hyperresponsive to pathogen infection. Proc Natl Acad Sci USA 1999, 96(24):14165-14170.

17. Bittel P, Robatzek S: Microbe-associated molecular patterns (MAMPs) probe plant immunity. Curr Opin Plant Biol 2007, 10(4):335-341.

18. Schulze-Lefert P, Panstruga R: A molecular evolutionary concept connecting nonhost resistance, pathogen host range, and pathogen speciation. Trends Plant Sci 2011, 16(3):117-125.

19. Wrather JA, Koenning SR: Estimates of disease effects on soybean yields in the United States 2003-2005. J Nematol 2006, 38:173-180.

20. Sandhu D, Gao H, Cianzio S, Bhattacharyya MK: Deletion of a disease resistance nucleotide-binding-site leucine-rich-repeat-like sequence is associated with the loss of the Phytophthora resistance gene Rps4 in soybean. Genetics 2004, 168(4):2157-2167.

21. Sandhu D, Schallock KG, Rivera-Velez N, Lundeen P, Cianzio S, Bhattacharyya MK: Soybean phytophthora resistance gene Rps8 maps closely to the Rps3 region. J Hered 2005, 96(5):536-541.

22. Burnham KD, Dorrance AE, VanToai TT, St Martin SK: Quantitative trait loci for partial resistance to Phytophthora sojae in soybean. Crop Sci 2003, 43 (5):1610-1617.

23. Koch E, Slusarenko A: Arabidopsis is susceptible to infection by a downy mildew fungus. Plant Cell 1990, 2(5):437-445.

24. Bhattacharyya MK, Ward EWB: Expression of gene-specific and age-related resistance and the accumulation of glyceollin in soybean leaves infected with Phytophthora megasperma f. sp. glycinea. Physiol Plant Pathol 1986, 29(1):105-113.

25. Dietrich RA, Delaney TP, Uknes SJ, Ward ER, Ryals JA, Dangl JL: Arabidopsis mutants simulating disease resistance response. Cell 1994, 77(4):565-577.

26. Adie BAT, Perez-Perez J, Perez-Perez MM, Godoy M, Sanchez-Serrano J-J, Schmelz EA, Solano R: ABA is an essential signal for plant resistance to pathogens affecting JA biosynthesis and the activation of defenses in Arabidopsis. Plant Cell 2007, 19(5):1665-1681.

27. Bhadauria V, Miraz P, Kennedy R, Banniza S, Wei Y: Dual trypan-aniline blue fluorescence staining methods for studying fungus-plant interactions. Biotech Histochem 2010, 85(2):99-105.

28. Huang X, Li J, Bao F, Zhang X, Yang S: A gain-of-function mutation in the Arabidopsis disease resistance gene RPP4 confers sensitivity to low temperature. Plant Physiol 2010, 154(2):796-809.

29. Kwon Y, Kim S, Jung M, Kim M, Oh J, Ju H: Arabidopsis hot2 encodes an endochitinase-like protein that is essential for tolerance to heat, salt and drought stresses. Plant J 2006, 49(2):184-193. 
30. Bell CJ, Ecker JR: Assignment of 30 microsatellite loci to the linkage map of Arabidopsis. Genomics 1994, 19(1):137-144.

31. Jiang RHY, Tripathy S, Govers F, Tyler BM: RXLR effector reservoir in two Phytophthora species is dominated by a single rapidly evolving superfamily with more than 700 members. Proc Natl Acad Sci USA 2008, 105(12):4874-4879.

32. Wang Q, Han C, Ferreira AO, Yu X, Ye W, Tripathy S, Kale SD, Gu B, Sheng Y, Sui $Y$, et al: Transcriptional programming and functional interactions within the Phytophthora sojae RXLR effector repertoire. Plant Cell 2011, 23 (6):2064-2086.

33. Michelmore RW, Paran I, Kesseli RV: Identification of markers linked to disease-resistance genes by bulked segregant analysis: a rapid method to detect markers in specific genomic regions by using segregating populations. Proc Natl Acad Sci USA 1991, 88(21):9828-9832.

34. Sahu B, Sumit R, Srivastava S, Bhattacharyya M: Sequence based polymorphic (SBP) marker technology for targeted genomic regions: its application in generating a molecular map of the Arabidopsis thaliana genome. BMC Genomics 2012, 13(1):20.

35. Huynh TV, Dahlbeck D, Staskawicz BJ: Bacterial blight of soybean: Regulation of a pathogen gene determining host cultivar specificity. Science 1989, 245(4924):1374-1377.

36. Wen Y, Wang W, Feng J, Luo M-C, Tsuda K, Katagiri F, Bauchan G, Xiao S: Identification and utilization of a sow thistle powdery mildew as a poorly adapted pathogen to dissect post-invasion non-host resistance mechanisms in Arabidopsis. J Exp Bot 2010, 62(6):2117-2129.

37. Tyler BM: Phytophthora sojae: root rot pathogen of soybean and model oomycete. Mol Plant Pathol 2007, 8(1):1-8.

38. Lipka U, Fuchs R, Kuhns C, Petutschnig E, Lipka V: Live and let die Arabidopsis nonhost resistance to powdery mildews. Eur J Cell Biol 2010, 89(2-3):194-199.

39. Tinoco M, Dias B, Dall'Astta R, Pamphile J, Aragao F: In vivo trans-specific gene silencing in fungal cells by in planta expression of a doublestranded RNA. BMC Biology 2010, 8(1):27.

40. Iqbal M, Yaegashi S, Ahsan R, Shopinski K, Lightfoot D: Root response to Fusarium solani f. sp. glycines: temporal accumulation of transcripts in partially resistant and susceptible soybean. Theor Appl Genet 2005, 110(8):1429-1438.

41. Weigel D, Glazebrook J: A Laboratory Manual: Cold Spring Harbor Lab Press. Arabidopsis 2002.

42. Lukowitz W, Gillmor CS, Scheible W-R: Positional cloning in Arabidopsis Why it feels good to have a genome initiative working for you. Plant Physiol 2000, 123(3):795-806.

43. Krapp A, Hofmann B, Schafer C, Stitt M: Regulation of the expression of $r b c S$ and other photosynthetic genes by carbohydrates: a mechanism for the 'sink regulation' of photosynthesis? Plant J 1993, 3(6):817-828.

44. Mishina T, Zeier J: Bacterial non-host resistance: interactions of Arabidopsis with non-adapted Pseudomonas syringae strains. Physiol plantarum 2007, 131(3):448-461.

45. Werres S, Marwitz R, Veld W, De Cock A, Bonants PJM, De Weerdt M, Themann K, llieva E, Baayen RP: Phytophthora ramorum sp nov., a new pathogen on Rhododendron and Viburnum. Mycol Res 2001, 105:1155-1165.

doi:10.1186/1471-2229-12-87

Cite this article as: Sumit et al:: Arabidopsis nonhost resistance gene PSS1 confers immunity against an oomycete and a fungal pathogen but not a bacterial pathogen that cause diseases in soybean. BMC Plant Biology 2012 12:87.

\section{Submit your next manuscript to BioMed Central and take full advantage of:}

- Convenient online submission

- Thorough peer review

- No space constraints or color figure charges

- Immediate publication on acceptance

- Inclusion in PubMed, CAS, Scopus and Google Scholar

- Research which is freely available for redistribution 